\title{
$\frac{100}{\text { LAT }}$ RPEiS
}

\section{O DOPUSZCZALNOŚCI ANTYCYPUJĄCEGO ODRZUCENIA SPADKU W PRAWIE POLSKIM}

\section{WPROWADZENIE}

Podstawowym sposobem uniknięcia odpowiedzialności za długi spadkowe jest odrzucenie spadku. Dominuje pogląd, że uprawnieni do odrzucenia spadku są wyłącznie spadkobiercy, natomiast osoby dziedziczące w drugiej i dalszej kolejności (tj. słabiej powołane do spadku1) odrzucić spadku nie moga, chyba że osoby silniej powołane ${ }^{2}$ nie chca lub nie moga być spadkobiercami ${ }^{3}$. W praktyce jednak osoby słabiej powołane, z obawy przed odziedziczeniem długów spadkowych, składają oświadczenie o odrzuceniu spadku niezwłocznie po uzyskaniu informacji o śmierci spadkodawcy, a zarazem jeszcze przed nadejściem chwili, w której można stwierdzić, że osoby silniej powołane do spadku nie chca lub nie mogą być spadkobiercami. Odrzucenie spadku określane jest wówczas mianem antycypującego ${ }^{4}$, a czynność prawna kwalifikowana jako dokonana pod warunkiem, że odrzucajacy zostanie spadkobierca, co powoduje jej bezwzględną nieważność (art. 1018 § 1 k.c.). Przy tak rygorystycznym ujęciu osoba słabiej powołana, wbrew swojemu

* Tomasz Jasiakiewicz, Uniwersytet Mikołaja Kopernika w Toruniu, tomjot@umk.pl, https://orcid.org/0000-0003-4679-0442

${ }^{1}$ Pojęciem spadkobiercy słabiej powołanego posługuje się Gwiazdomorski (1985): 140, w kontekście art. 1024 k.c. Osoba dziedzicząca w drugiej lub dalszej kolejności, która odrzuca spadek przed spadkobiercami silniej powołanymi, jest jedynie potencjalnym spadkobierca, dlatego uzasadnione jest posługiwanie się względem niej co najwyżej pojęciem o s oby słabiej powołanej do spadku.

${ }^{2}$ Co do pojęcia spadkobiercy silniej powołanego względnie osoby silniej powołanej por. m.in. Gwiazdomorski (1985): 136; Pisuliński (1992): 60; Borysiak (2013): 462.

${ }^{3}$ Uchwały SN: z 19 października 2018 r., III CZP 36/18, Lex nr 2565847; z 23 października 2019 r., III CZP 23/19, Lex nr 2729948; Pisuliński (1992): 61; Szymańska (2010): 277; Kuźmicka-Sulikowska (2019): 2064; Borysiak (2019): 1004; Szpyt (2019): 2096; Justyński (2019): 56; Wolak (2019): 138 n.; Zelek (2019): 113; Berek (2019): 38; Żok (2019): 1497.

${ }^{4}$ Por. uzasadnienie uchwały SN z 19 października 2018 r., III CZP 36/18. 
przeświadczeniu o skuteczności dokonanej czynności prawnej, i tak nabywa spadek (z dobrodziejstwem inwentarza) z chwilą upływu terminu na przyjęcie lub odrzucenie spadku (art. 1015 § 2 k.c.), stając się w ten sposób osobiście odpowiedzialną za długi spadkowe. W konsekwencji wobec wierzycieli spadkowych odpowiada ona nie tylko przedmiotami wchodzącymi w skład odziedziczonego spadku, lecz całym swoim majątkiem, jako że w tym okresie ograniczenie odpowiedzialności osobistej ma jedynie charakter kwotowy (art. $1031 \S 2 \mathrm{w}$ zw. z art. 1030 zd. 2 k.c.). Warto mieć na uwadze fakt, że nawet przy dołożeniu należytej staranności w ustalaniu kolejności dziedziczenia w celu uniknięcia odrzucenia spadku w sposób antycypujący, może się ostatecznie okazać, iż oświadczenie o odrzuceniu - sprzecznie z intencjami odrzucającego - zostało jednak dokonane „na zapas”.

Zaaprobowanie i w konsekwencji zastosowanie przez sąd konstrukcji antycypującego odrzucenia spadku staje się wówczas jedynym sposobem uchronienia osób słabiej powołanych do spadku przed jego mimowolnym przyjęciem oraz wynikająca z tego niezasłużoną i zagrażająca ich interesom ${ }^{5}$ odpowiedzialnością za długi spadkowe.

Niniejsze opracowanie oparto na założeniu, że de lege lata w zakresie autonomii woli ${ }^{6}$ mieści się możliwość złożenia antycypującego oświadczenia o odrzuceniu spadku. Ponadto krytycznej analizie poddano utrwalony w doktrynie i judykaturze pogląd ${ }^{7}$, zgodnie z którym niedopuszczalne jest odrzucenie spadku „na zapas”. Omówiono także szczególny przypadek, gdy uprawniony do zachowku składa antycypujące oświadczenie o odrzuceniu spadku z tytułu ustawy, pomimo że dziedziczenie następuje na podstawie testamentu. W założeniu odrzucającego dalszy zstępny spadkodawcy (z uwagi na swoją małoletniość) miałby dzięki temu uzyskać relatywnie większy zachowek. Takie działanie jest kwestionowane nie tylko z powodu antycypującego charakteru złożonego oświadczenia, lecz także z uwagi na motywację, którą kieruje się odrzucający spadek $^{9}$.

\section{NATURA PRAWNA ANTYCYPUJĄCEGO ODRZUCENIA SPADKU}

Mówiąc o antycypującym odrzuceniu spadku, należy wyróżnić dwie sytuacje. W pierwszej potencjalny spadkobierca składa oświadczenie o odrzuceniu spadku, zanim jego tytuł powołania zdążył się zaktualizować, a więc antycy-

${ }^{5} \mathrm{Na}$ temat zagrożeń płynących z przyjęcia spadku z dobrodziejstwem inwentarza por. Swaczyna (2013): 576 n.; Księżak (2015): 875 n.; Berek (2019): 43 n.

${ }^{6}$ Co do znaczenia pojęcia autonomii woli w prawie cywilnym zob. Mularski, Radwański (2019): $13 \mathrm{n}$.

7 Por. przyp. 3.

8 Za konstrukcją antycypującego odrzucenia spadku opowiadają się: Księżak (2014): 107, przyp. 5; Księżak (2015): 888, przyp. 38; Księżak (2017): 374; Kucia (2017): 226 n.; Gorczyński (2018): 563; Pazdan (2021): 1284 n.

9 Por. uchwała SN z 23 października 2019 r., III CZP 23/19. 
pująco w znaczeniu obiektywnym. Wskazana osoba, składając przedmiotowe oświadczenie, może przy tym mieć świadomość, że działa z wyprzedzeniem, bądź też może być przekonana co do tego, że termin z art. 1015 k.c. już rozpoczął swój bieg.

W drugiej sytuacji natomiast odrzucajacy ma już status spadkobiercy, jednakże w chwili składania oświadczenia jest on przekonany, że powołanie osób dziedziczących w bliższej kolejności wciąż wyłącza jego powołanie. Odrzucenie spadku należy wówczas postrzegać jako złożone antycypująco w znaczeniu subiektywnym.

Przy ocenie pierwszego z wymienionych przypadków prima facie może nasuwać się wniosek, że oświadczenie o odrzuceniu spadku nie wywołuje skutku prawnego, skoro składająca je osoba jest jedynie potencjalnym spadkobierca. Przeciwko trafności tego poglądu przemawia jednak istotny argument odwołujący się do przyjętej na gruncie prawa polskiego konstrukcji retroaktywnego nabycia spadku. W konsekwencji w przypadku osób słabiej powołanych do spadku zachodzi chronologiczna rozbieżność pomiędzy zdarzeniem, od którego uzależnione jest dziedziczenie ${ }^{10}$, a wystapieniem skutku w postaci nabycia spadku. Nabycie spadku w odniesieniu do ww. osób wyprzedza bowiem moment zaistnienia przesłanki warunkującej nabycie, jako że następuje zawsze $\mathrm{z}$ chwilą otwarcia spadku ${ }^{11}$. Dlatego więc status spadkobiercy przysługuje słabiej powołanemu już od momentu śmierci spadkodawcy. Prawo do antycypującego odrzucenia spadku już z tego powodu nie może być kwestionowane. Z cała pewnością należy to wyłączyć w sytuacji, w której dana osoba ostatecznie nabędzie z mocą wsteczną status spadkobiercy. Wówczas czynność traci bowiem z mocą wsteczną charakter (w założeniu jedynie tymczasowy) czynności prawnej dokonanej antycypująco. Przyjęcie odmiennego założenia, zgodnie z którym odrzucenie spadku „na zapas” nie jest możliwe, podważałoby w pewnym zakresie retroaktywna moc tymczasowego nabycia spadku. Nabycie spadku następowałoby bowiem ze skutkiem ex tunc, natomiast prawo do odrzucenia spadku - wbrew przyjętej konstrukcji retroaktywnego nabycia spadku - powstawałoby tylko na przyszłość, tj. ze skutkiem ex nunc. Dlatego też należy przyjaćc, że prawo do odrzucenia spadku jako immanentnie związane ze statusem spadkobiercy, nabywane jest z chwilą śmierci spadkodawcy, także gdy spadkobiercy są słabiej powołani do spadku.

Zastosowanie konstrukcji retroaktywnego nabycia spadku pozwala na sformułowanie wniosku, że okres kształtowania się kręgu spadkobierców z natury swej ma jedynie charakter przejściowy. Z chwila przyjęcia spadku przez wszystkich spadkobierców okres ten zasadniczo należy więc uważać za niebyły. Ewentualnym odstępstwom w tym względzie ustawodawca dał wyraz w sposób wyraźny (por. np. art. 1021 k.c.). Z uwagi na tak ukształtowana specyfikę okresu wyłaniania definitywnych spadkobierców czas jego trwania powinien być jak najkrótszy. W przypadku niedopuszczenia możliwości anty-

${ }^{10} \mathrm{~W}$ praktyce chodzi w szczególności o odrzucenie spadku przez osobę silniej powołaną do spadku.

11 Kucia (2017): 226 n. 
cypującego odrzucenia spadku realizacja tego postulatu byłaby jednak w praktyce znacznie utrudniona.

W kontekście antycypującego odrzucenia spadku kwestia jego retroaktywnego nabycia jest na ogół pomijana, co sprawia, że takie odrzucenie kwalifikowane jest jako czynność prawna zastrzeżona warunkiem ${ }^{12}$. Mogłoby się wydawać, że skoro potencjalny spadkobierca składa swoje oświadczenie „na zapas", to w istocie odrzuca spadek pod warunkiem, że zostanie spadkobierca. To oznacza z kolei, że czynność jest dotknięta sankcją bezwzględnej nieważności (art. 1018 § 1 k.c.) ${ }^{13}$. Z takim stanowiskiem nie sposób się zgodzić przede wszystkim z uwagi na znaczenie pojęcia warunku na gruncie art. $1018 \S 1$ k.c.

W prawie cywilnym warunkowi przypisuje się dwa znaczenia. Po pierwsze, tym pojęciem określa się postanowienie zaliczane do accidentalia negotii treści czynności prawnej, które służy uzależnieniu jej skutków od wystapienia zdarzenia przyszłego i niepewnego ${ }^{14}$. Po drugie, warunek może występować jako synonim zdarzenia przyszłego i niepewnego. Przykładem w tym względzie jest art. 962 zd. 3 k.c., który stanowi o „ziszczeniu się albo nieziszczeniu się warunku”. Nie ulega wątpliwości, że w art. 1018 § 1 k.c. ustawodawca posługuje się pierwszym ze wskazanych znaczeń.

Powstaje wobec tego pytanie, czy w przypadku antycypującego odrzucenia spadku składajacy oświadczenie rzeczywiście uzależnia skuteczność dokonanej czynności prawnej od zaistnienia zdarzenia przyszłego i niepewnego, naruszając tym samym zakaz wynikajacy z art. 1018 § 1 k.c. W tym względzie, co do zasady, należy udzielić odpowiedzi negatywnej. W praktyce potencjalny spadkobierca nie uzależnia bowiem skuteczności odrzucenia spadku od tego, czy ostatecznie dojdzie do dziedziczenia, a ściśle rzecz biorąc, nie formułuje postanowienia o takiej treści w ramach dokonywanej jednostronnej czynności prawnej. Przyjęcie założenia, że w tym przypadku odrzucenie następuje z zastrzeżeniem warunku w rozumieniu art. $1018 \S 1$ k.c., byłoby dopuszczalne jedynie w sytuacji, w której istniałaby wyraźna regulacja kwalifikujacca antycypujące odrzucenie spadku jako odrzucenie dokonane z zastrzeżeniem warunku. Taka regulacja nie została jednak przewidziana w Kodeksie cywilnym. Natomiast wywodzenie zastrzeżenia warunku jedynie z okoliczności zewnętrznych, tj. z faktu, że tytuł powołania wobec odrzucającego do chwili złożenia oświadczenia nie zdążył się jeszcze zaktualizować, stanowi nadinterpretację jego wyraźnego oświadczenia woli. Jest ona tym bardziej nieuzasadniona, że w założeniu ma doprowadzić do nieważności tej czynności prawnej. W tym kontekście szczególnego znaczenia nabiera fakt, że odrzucenie spadku jest czynnością prawną sformalizowaną (art. 1018 § 3 k.c.). Przedmiotowe oświadczenie musi być bowiem złożone przed sądem lub przed notariuszem, przy czym może to nastapić ustnie lub na piśmie z podpisem urzędowo po-

12 Tak SN w uchwale z 19 października 2018 r., III CZP 36/18; Pisuliński (1992): 61; Szymańska (2010): 277; Justyński (2019): 56; Wolak (2019): 139; Borysiak (2019): 1004; Berek (2019): $38 \mathrm{n}$.

13 SN w uchwale z 19 października 2018 r., III CZP 36/18, powołując się na art. 1018 § 1 k.c., uznał taką czynność za ,bezskuteczną”.

14 Swaczyna (2012): 29 n. 
świadczonym (art. 1018 § 3 k.c.). W tej sytuacji treść odrzucenia spadku jest kształtowana wyłącznie przez oświadczenie złożone w taki właśnie sposób. Tym samym zastrzeżenia warunku nie można wywodzić z okoliczności towarzyszących odrzuceniu spadku, tj. z faktu, że czynność jest dokonywana zanim spełnią się przesłanki, od których zależy dziedziczenie danego spadkobiercy. W tym obszarze normatywnym kwestia zastrzeżenia warunku w sposób dorozumiany (per facta concludentia) w ogóle nie może być rozważana ${ }^{15}$.

Jeżeli już w analizowanej sytuacji wskazywać na warunek, to de lege lata należy stwierdzić obowiązywanie warunku prawnego (conditio iuris), a nie warunku w rozumieniu art. 89 k.c. ${ }^{16}$ Wprawdzie zastosowanie conditio iuris przez ustawodawcę nie wynika wyraźnie z przepisów ustawy, jednakże wpisuje się w pełni w ramy retroaktywnego nabycia spadku, współtworząc całą konstrukcję. Pozbawione conditio iuris retroaktywne nabycie spadku byłoby instytucją niepełna, a przez to wyraźnie niespójna. Sytuacja z konstrukcyjnego punktu widzenia przedstawia się zatem w sposób następujący. Osobę słabiej powołaną do spadku należy uznać za uprawnioną do odrzucenia spadku „na zapas”, przy czym skuteczność takiej czynności jest uzależniona od tego, czy zaktualizują się wobec niej ustawowe przesłanki dziedziczenia. Jeżeli wskazane przesłanki wystapia, to odrzucenie spadku należy uznać za skuteczne. Jeżeli natomiast do tego nie dojdzie, to odrzucenie spadku pozostanie bezskuteczne, choć bez watpienia ważne.

Obowiązywanie conditio iuris rodzi również pytanie o skutki prawne odrzucenia spadku z zastrzeżeniem warunku w rozumieniu art. 89 k.c. Nie można bowiem wyłączyć możliwości zaistnienia w praktyce takich wyjątkowych sytuacji, w których potencjalny spadkobierca, nie zważając na obowiązywanie conditio iuris, zdecyduje się na dodanie do treści czynności prawnej postanowienia o warunku (w rozumieniu art. 89 k.c.), w ramach którego skuteczność odrzucenia spadku uzależni od tego, czy zostanie spadkobierca. Ogólnie rzecz biorąc, zdarzenie przyszłe i niepewne może zatem stać się nie tylko przedmiotem conditio iuris, lecz również warunku w rozumieniu art. 89 k.c. W doktrynie przyjmuje się, że $\mathrm{w}$ takiej sytuacji conditio iuris nie ulega przekształceniu w warunek w znaczeniu art. 89 k.c., a wskazane dodatkowe zastrzeżenie należy rozpatrywać co najwyżej w kategoriach superfluum ${ }^{17}$. Przywołany pogląd zdaje się wskazywać, że obydwa warunki nie moga funkcjonować jednocześnie, a conditio iuris ma pierwszeństwo przed warunkiem wynikającym z treści czynności prawnej. Takie ujęcie zasługuje na aprobatę. W analizowanym przypadku należy zatem dojść do wniosku, że osoba słabiej powołana do spadku w wyniku posłużenia się warunkiem (art. 89 k.c.) w żadnym razie nie jest władna zawiesić skuteczności odrzucenia spadku, skoro na zasadzie wyłączności czyni to sam ustawodawca w ramach bezwzględnie obowiązujących

15 Co do warunku dorozumianego por. Gorczyński (2012): 137.

16 Por. Kucia (2017): 227, przyp. 49; Gorczyński (2018): 563; tak też na tle $§ 1946$ BGB m.in. Leipold (2013a): 235.

17 Swaczyna (2012): 61; w prawie niemieckim takie działanie uznaje się za „nieszkodliwe”, jakkolwiek $§ 1947$ BGB tak samo jak art. 1018 k.c. zakazuje przyjmowania lub odrzucania spadku z zastrzeżeniem warunku lub terminu - por. Leipold (2013b): 236. 
przepisów. Z tego względu zastrzeżenie dodatkowego warunku powinno być traktowane co najwyżej jako próba osiagnięcia skutków prawnych, które i tak zostały już przewidziane przez ustawodawcę. Ad casum może się zresztą okazać, że takie działanie służy wyłącznie ujawnieniu przez potencjalnego spadkobiercę wiedzy o istnieniu ustawowej warunkowości odrzucenia spadku „na zapas". Conditio iuris w ogóle nie wchodzi wówczas w interakcję z - w istocie niezastrzeżonym - warunkiem w rozumieniu art. 89 k.c. Jeżeli jednak intencja takiego spadkobiercy jest osiagnięcie skutków przewidzianych w art. 89 k.c., to warunek zastrzeżony przez niego jest bezskuteczny. O innych negatywnych konsekwencjach tego rodzaju działania nie może być mowy. W szczególności $\mathrm{w}$ analizowanej sytuacji nie ma podstaw do objęcia odrzucenia spadku sankcja przewidzianą w art. 1018 \$ 1 k.c. Przedmiotowa czynność nie może być uznana za nieważną tylko z tego powodu, że osoba słabiej powołana intuicyjnie powieliła obowiązująca regulację ustawowa. Wbrew pozorom zakres zakazu wynikającego z art. 1018 § 1 k.c. doznaje zatem istotnych ograniczeń i nie obejmuje wszystkich przypadków przyjęcia lub odrzucania spadku z zastrzeżeniem warunku.

Kwestionowanie możliwości antycypującego odrzucenia spadku trudno również pogodzić z instytucją transmisji (art. 1017 k.c.). Może się zdarzyć, że śmierć osoby słabiej powołanej do spadku, która z wyprzedzeniem złożyła oświadczenie o odrzuceniu spadku, nastapi, zanim zdezaktualizuje się powołanie do spadku spadkobierców silniej powołanych. Przy założeniu, że antycypujące odrzucenie spadku nie jest dopuszczalne, należałoby przyjąć, że uprawnienie do przyjęcia lub odrzucenia spadku nie zostało skutecznie wykorzystane i w ramach transmisji wchodzi ono w skład spadku (art. 1017 k.c.). Transmitariusz mógłby wówczas spadek po pierwszym spadkodawcy przyjąć, ponieważ oświadczenie złożone przez transmitenta nie byłoby dla niego wiążące. Przy takim ujęciu transmisja straciłaby walor instytucji przewidzianej na wypadek zaistnienia szczególnej sytuacji faktycznej, w której spadkobierca przed śmiercią nie zdążył złożyć oświadczenia o przyjęciu lub odrzuceniu spadku. W pełni usprawiedliwione byłoby wówczas stwierdzenie, że w przypadku osób, które zmarły, zanim ich powołanie zdążyło się zaktualizować, transmisja ma charakter przymusowy. W zasięgu możliwości transmitenta pozostawałby jedynie wybór spadkobiercy testamentowego, który występując w roli transmitariusza, podzielałby jego pogląd o konieczności odrzucenia spadku po pierwszym spadkodawcy. Nawet wówczas nie miałby on jednak pewności, że transmitariusz spadek odrzuci. Przy takim ujęciu dochodziłoby zatem do powstania poważnej nierównowagi pomiędzy sytuacją prawną spadkobierców dziedziczących spadek w pierwszej kolejności a sytuacją osób słabiej powołanych do spadku. Tego rodzaju nierównowagi nie sposób pogodzić z wyrażona w art. 32 Konstytucji zasadą równości wobec prawa.

Za dopuszczalnością antycypującego odrzucenia spadku przemawiaja również doniosłe względy praktyczne ${ }^{18}$. Nawet dołożenie przez potencjalnego spadkobiercę należytej staranności w ustalaniu chwili, w której aktualizuje się jego tytuł powołania do spadku, nie daje gwarancji prawidłowego jej

18 Por. na ten temat Berek (2019): $41 \mathrm{n}$. 
ustalenia. Innymi słowy, niezależnie od wykazania się należytą starannościa może się okazać, że oświadczenie zostało jednak złożone „na zapas”. Przyczyny takiej sytuacji moga być rozmaite. Przede wszystkim jednak przekazywane zainteresowanemu informacje o odrzuceniu spadku przez osoby powołane w bliższej kolejności nie muszą być zgodne z prawdą. Warto w tym kontekście zauważyć, że nie istnieje żaden publiczny rejestr takich oświadczeń, a wskazane osoby nie są obarczone obowiązkiem informowania dalszych uprawnionych o złożeniu oświadczenia o odrzuceniu spadku. Udostępnienie takiej informacji zależy zatem jedynie od ich dobrej woli. Ponadto krewni mogą być są ze sobą skonfliktowani bądź też, z uwagi na dalsze pokrewieństwo, nie utrzymywać ze sobą żadnych kontaktów. Częste są także sytuacje, w których potencjalny spadkobierca w ogóle nie zdaje sobie sprawy z istnienia innych jeszcze osób uprawnionych do dziedziczenia. W praktyce - wbrew intencjom odrzucajacego - odrzucenie spadku, nawet przy dołożeniu należytej staranności, już post factum może się okazać odrzuceniem dokonanym „na zapas”. Jeżeli w takiej sytuacji konstrukcja antycypującego odrzucenia spadku zostanie zakwestionowana, to czynność trzeba by ponowić. Jeżeli natomiast spadkobierca nie zdawałby sobie sprawy z konieczności powtórzenia czynności, to z chwilą upływu terminu przewidzianego w art. 1015 § 1 k.c. doszłoby do nieświadomego i mimowolnego ${ }^{19}$ nabycia przez niego spadku z dobrodziejstwem inwentarza. Spadkobierca może wówczas poszukiwać ochrony jedynie w konstrukcji uchylenia się od skutków prawnych niezachowania terminu z uwagi na błąd co do prawa (art. 1019 k.c.) ${ }^{20}$. Z wielu powodów nie jest to jednak rozwiąanie, które w pełni zabezpieczałoby jego interesy ${ }^{21}$.

W drugiej sytuacji (por. pkt II ab initio), gdy antycypujace odrzucenie spadku występuje w znaczeniu subiektywnym, słabiej powołany składa oświadczenie o odrzuceniu spadku, zanim dowie się, że tytuł jego powołania już stał się skuteczny. Tym samym w chwili dokonywania czynności prawnej ma on już status spadkobiercy tymczasowego, choć nie jest tego świadomy. Występuje zatem niezgodność pomiędzy obiektywną rzeczywistością a stanem wiedzy składającego oświadczenie o odrzuceniu spadku. W tym kontekście wątpliwości budzi stanowisko SN wyrażone w uchwale z 19 października 2018 r., zgodnie z którym „złożenie oświadczenia o odrzuceniu spadku przez osobę, w stosunku do której nie rozpoczą jeszcze biegu termin określony w art. 1015 $\S 1$ k.c., jest bezskuteczne" 22 . Trudno zresztą rozstrzygnać, czy zdaniem składu orzekającego zaprezentowany w uchwale pogląd miałby znaleźć zastosowanie również $\mathrm{w}$ przypadku antycypującego odrzucenia spadku w znaczeniu subiektywnym. Sam fakt, że spadkobierca w chwili składania oświadczenia nie wie o tytule swojego powołania, nie oznacza jeszcze, że nie ma on statusu (tymczasowego) spadkobiercy (tj. statusu, który bezspornie pozwala złożyć oświadczenie o przyjęciu lub odrzuceniu spadku). Ratio legis art. $1015 \S 1$ k.c.,

\footnotetext{
${ }^{19}$ Co do pojęcia mimowolnego przyjęcia spadku zob. Jasiakiewicz (2019): 125 n.

20 Borysiak (2019): 1009.

21 Por. szerzej Berek (2019): 44.

22 Uchwała SN z 19 października 2018 r., III CZP 36/18.
} 
który zakłada powiązanie początku biegu terminu z faktem uzyskania przez spadkobiercę wiedzy o tytule jego powołania, ma w założeniu zabezpieczać go przed nieświadomym, a w konsekwencji mimowolnym definitywnym nabyciem spadku. Z konstrukcyjnego punktu widzenia tego rodzaju regulacje nie rozstrzygają zatem o powstaniu uprawnienia; ich rola sprowadza się raczej do wskazania chwili, w której ono wygasa. Jeżeli więc rozważać wpływ regulacji art. 1015 § 1 k.c. na kształt uprawnienia do odrzucenia spadku, to ogranicza się on wyłącznie do określenia chwili ustania tego uprawnienia. Kwestia związana $\mathrm{z}$ momentem powstania przedmiotowego uprawnienia nie jest natomiast objęta regulacją art. $1015 \S 1$ k.c. Analizując wskazane zagadnienie, należy zatem wyjść od istoty terminów zawitych na gruncie prawa cywilnego. Dowodzi tego między innymi treść art. 88 k.c., który przecież nie stoi na przeszkodzie uchyleniu się od skutków prawnych oświadczenia złożonego pod wpływem groźby, choćby nawet stan obawy jeszcze nie ustał ${ }^{23}$.

Analizując dopuszczalność antycypującego odrzucenia spadku, warto również posłużyć się argumentem natury prawnoporównawczej. Należy zauważyć, że w niemieckim prawie spadkowym również nie ma wyraźnego odniesienia do sytuacji, w której osoba składa oświadczenie o odrzuceniu spadku „na zapas”. Relewantny w tym zakresie przepis § 1946 BGB stanowi jedynie, że: „Spadkobierca może spadek przyjacć lub odrzucić, skoro tylko nastapi otwarcie spadku". Mimo że wskazany przepis daje asumpt do rozmaitych interpretacji, doktryna niemiecka jest zgodna co do tego, że osoby słabiej powołane do spadku mogą na jego podstawie odrzucić spadek w sposób antycypujaccy ${ }^{24}$. W $§ 1946$ BGB dostrzega się przy tym obowiązywanie conditio iuris ${ }^{25}$, w związku z czym skuteczność złożonego oświadczenia jest zawieszona do momentu zaktualizowania się w stosunku do potencjalnego spadkobiercy tytułu powołania do spadku. Jeżeli wskazana przesłanka się nie ziści, oświadczenie nie wywoła skutków prawnych. Ustawodawca niemiecki, kształtując treść § 1946 BGB, nie widział zatem potrzeby, aby conditio iuris, na której oparta jest konstrukcja antycypujacego odrzucenia spadku, uregulować expressis verbis. Brak w prawie polskim wyraźnej regulacji dopuszczajacej antycypujące odrzucenie spadku trudno wobec tego uznać za podstawę do kwestionowania de lege lata tej konstrukcji.

Warto także zauważyć, że obowiązywanie de lege lata wskazanej wyżej conditio iuris, wyklucza możliwość uznania antycypującego odrzucenia spadku za czynność prawną bezprzedmiotową ${ }^{26}$. Nie ma także podstaw do przyjęcia, że spadkobiercom słabiej powołanym do spadku nie przysługuje zdolność prawna w zakresie odrzucenia spadku „na zapas”.

${ }^{23}$ Co do znaczenia art. $1015 \S 1$ k.c. dla określania chwili powstania uprawnienia do przyjęcia lub odrzucenia spadku por. Justyński (2019): $55 \mathrm{n}$.

${ }^{24}$ Leipold (2013a): 235; Siegmann, Höger (2012a): 1437; Trimborn von Landenberg (2011a): 88; Masloff (2011a): 155.

${ }^{25}$ Leipold (2013b): 236; Siegmann, Höger (2012b): 1438; Trimborn von Landenberg (2011b): 89; Masloff (2011b): 156.

26 Tak Żok (2019): 1497. 


\section{ZNACZENIE ANTYCYPUJACCEGO ODRZUCENIA SPADKU DLA PRAWIDLOWEGO STOSOWANIA PRZEPISÓW O ZACHOWKU}

Dotychczasowe rozważania w sposób ogólny traktowały o konstrukcji antycypującego odrzucenia spadku. Punktem odniesienia dalszych rozważań będzie natomiast znany orzecznictwu przypadek, gdy w ramach dziedziczenia testamentowego zstępny spadkodawcy składa oświadczenie o odrzuceniu spadku z ustawy, przy czym, co nie mniej ważne, spadek przedstawia znaczną wartość majątkową ${ }^{27}$. Powody, dla których to czyni, z początku trudne do określenia, przy bliższej analizie można je jednak ustalić. Takie, zdawałoby się nieracjonalne, działanie wynika z przyjętego przez zstępnego spadkodawcy założenia, że przewidziana w art. 1020 k.c. fikcja prawna dotyka również osób, które odrzuciły spadek z ustawy, nie będąc spadkobiercami ustawowymi. Zstępny spadkodawcy liczy zatem na to, że wskutek dokonanej czynności prawnej będzie on traktowany tak, jakby nie dożył chwili otwarcia spadku (art. 1020 k.c.). To z kolei ma znaczenie w świetle przepisów o zachowku. Jeżeli bowiem odrzucenie spadku miałoby powodować tego rodzaju konsekwencje, to prawo do zachowku nie przysługiwałoby dłużej odrzucającemu, lecz uprawnionym z tego tytułu stałby się jego zstępny, będący jednocześnie dalszym zstępnym spadkodawcy. Ten z kolei, z uwagi na swoją małoletniość, zgodnie z art. $991 \S 1$ k.c., mógłby liczyć na relatywnie wyższy zachowek, aniżeli odrzucajacy spadek.

Kwestia prawidłowej kwalifikacji dokonanej czynności prawnej, z uwagi na szczególną motywację odrzucającego spadek, z początku budzi pewne wątpliwości. Można nawet odnieść wrażenie, że wskazana sytuacja wykracza poza zakres tematyczny niniejszego opracowania, ponieważ nie dotyczy problematyki odrzucania spadku „na zapas”. Niemniej jednak bliższa analiza pozwala stwierdzić, że in casu również dochodzi do antycypującego odrzucenia spadku, jakkolwiek jest ono dokonywane pod wpływem szczególnej motywacji. Taki wniosek opiera się na przyjętym w niniejszym opracowaniu założeniu, że odrzucenie spadku ma charakter antycypujący, jeżeli do odrzucenia spadku dochodzi w okresie pomiędzy otwarciem spadku a chwilą zaktualizowania się tytułu powołania do spadku. Nie ma przy tym znaczenia, jak duże jest prawdopodobieństwo dziedziczenia po danym spadkodawcy w chwili składania oświadczenia o odrzuceniu spadku. W konsekwencji skuteczność dokonanej czynności prawnej, zgodnie z konstrukcją antycypującego odrzucenia spadku, zależy od ziszczenia się conditio iuris $^{28}$. Jeżeli wskazany warunek się nie ziści, to odrzucenie spadku pozostanie bezskuteczne, a odrzucajacy spadek nie utraci prawa do zachowku. Motywacja osoby, która odrzuca spadek, nie wpływa zatem na sposób postrzegania samej czynności, którą mimo wszystko należy kwalifikować jako antycypujące odrzucenie spadku. Wskazana motywacja nabiera natomiast znaczenia w kontekście art. 1019 k.c. Jeżeli bowiem osoba

27 Por. uchwałę SN z 23 października 2019 r., III CZP 23/19.

28 Odmiennie Justyński (2020: 36): „odrzucenie spadku przez osobę, której nie przysługuje status spadkobiercy po zmarłym, pozbawione jest znaczenia prawnego”. 
słabiej powołana do spadku błędnie zakłada, że w wyniku odrzucenia spadku z tytułu ustawy będzie traktowana tak, jakby nie dożyła chwili otwarcia spad$\mathrm{ku}$, chociaż dziedziczenie nie następuje w reżimie ustawowym, to ewentualnie może się ona uchylić od skutków prawnych złożonego oświadczenia woli z uwagi na błąd co do prawa (art. 1019 k.c.). Z praktycznego punktu widzenia powołanie się na art. 1019 k.c. nie ma jednak większego sensu. W sytuacji gdy nie dojdzie do dziedziczenia ustawowego, odrzucenie spadku i tak nigdy nie wywoła skutków prawnych. Wypada jednocześnie zauważyć, że pomimo swojego antycypującego charakteru odrzucenie spadku nie może być odwołane (art. $1018 \S 2$ k.c.) $)^{29}$.

Przedmiotowa czynność nie powinna być przy tym uznawana za czynność mająca na celu obejście przepisów o zachowku. Taka kwalifikacja wiązałaby się z koniecznością zastosowania wobec odrzucenia spadku sankcji nieważności, ponieważ zasadniczo czynności prawne mające na celu obejście ustawy są z mocy prawa bezwzględnie nieważne (art. 58 § 1 k.c.) ${ }^{30}$. Wskazana kwestię można by oczywiście uznać za pozbawioną znaczenia. Niezależnie bowiem od tego, czy czynność zostanie uznana za bezskuteczna, z uwagi na nieziszczenie się warunku prawnego, czy też za nieważną z powodu naruszenia art. 58 § 1 k.c., odrzucajaccy spadek i tak nie utraci prawa do zachowku, a małoletni nie stanie się osobą uprawniona z tego tytułu. Przy formułowaniu takiego wniosku zupełnie pomija się natomiast sytuację, w której do ziszczenia się przedmiotowego warunku ostatecznie jednak dochodzi, a odrzucający spadek staje się spadkobiercą. Przyjęcie jednej ze wskazanych wyżej kwalifikacji bezpośrednio przekłada się wówczas na ocenę dokonanej czynności prawnej, która albo musiałaby zostać ponownie dokonana z uwagi na swoją nieważność, albo nabrałaby skuteczności aktualizując fikcję prawną przewidziana w art. 1020 k.c. Wbrew pozorom dokonanie prawidłowego wyboru ma zatem znaczenie. Uzasadnienie prezentowanego stanowiska należy zaczaćc od tego, że motywacja, którą kieruje się odrzucający spadek, z pewnością nie ma wpływu na skutki dokonywanej czynności prawnej. Jeżeli natomiast ustawa stanowi o czynnościach prawnych majacych na celu obejście ustawy, to chodzi o czynności, które stanowią pewne zagrożenie ze względu na skutki, jakie miałyby one wywoływać. Motywacja dokonującego czynności jest w tym kontekście prawnie irrelewantna, ponieważ sama w sobie nie jest źródłem skutków, które mogłyby wywoływać wskazane zagrożenie. Już z tego powodu antycypujące odrzucenie spadku nie może być uznane za czynność prawną mającą na celu obejście ustawy.

Bezskuteczność odrzucenia spadku we wskazanej wyżej sytuacji nie wynika również z naruszenia zasady numerus clausus jednostronnych czynności prawnych $^{31}$. Z pewnością odwołanie się do wskazanej zasady jest uprawnione

\footnotetext{
${ }^{29}$ W ramach uwag de lege ferenda kwestię tę dostrzega Berek (2019): 48.

${ }^{30} \mathrm{Na}$ temat nieważności czynności prawnej mającej na celu obejście ustawy por. Gutowski, Radwański (2019): 563.

31 Por. uchwałę SN z 23 października 2019 r., III CZP 23/19. Na temat swobody jednostronnych czynności prawnych por. Grykiel, Olejniczak, Radwański (2019): 252.
} 
w przypadku odrzucenia spadku przed śmiercią spadkodawcy ${ }^{32}$ czy też w razie odrzucenia roszczenia o zachowek ${ }^{33}$. Obie wskazane czynności nie figurują bowiem w zamkniętym katalogu jednostronnych czynności prawnych i już z tego powodu ich nieważność nie powinna budzić wątpliwości. Taki wniosek nie jest jednak uprawniony w przypadku konstrukcji określanej mianem antycypującego odrzucenia spadku. Wskazane odrzucenie nie stanowi bowiem nowej jednostronnej czynności prawnej, nieujętej w ramach przepisów prawa spadkowego. Nie ma przy tym znaczenia, że dokonanie przedmiotowej czynności prawnej jest motywowane chęcia zmiany kręgu osób uprawnionych do zachowku. Osoba pominięta w testamencie, której przysługuje prawo do zachowku, nie ma możliwości podjęcia samodzielnej decyzji o rezygnacji z tego prawa. Dopuszczalne jest jedynie zawarcie z zobowiązanym z tytułu zachowku umowy o zwolnienie $\mathrm{z}$ długu ${ }^{34}$, która jednak nie skutkuje nabyciem prawa do zachowku przez dalszego zstępnego. Bezspornie motywacja odrzucającego spadek nie wpisuje się $\mathrm{w}$ przewidziane prawem spadkowym konstrukcje. Jednocześnie jednak nie wpływa ona na treść dokonanej czynności prawnej, która wciąż należy kwalifikować jako antycypujące odrzucenie spadku. Takie odrzucenie jest natomiast dopuszczalne i w żadnym razie nie może być przedstawiane jako przykład czynności wykraczającej poza ustalony prawem katalog jednostronnych czynności prawnych.

Trudno również zgodzić się z poglądem, że odrzucenia spadku w opisanej wyżej sytuacji nie da się pogodzić z osobistym charakterem prawa do zachowku ${ }^{35}$. Rzeczywiście prawo do zachowku nie może być ani przedmiotem dyspozycji inter vivos, ani mortis causa. Zostało ono przyznane osobom wskazanym w art. 991 k.c. i rezygnacja z tego prawa z korzyścią dla innej wymienionej w art. 991 k.c. osoby, co do zasady, jest niedopuszczalna, chyba że taka możliwość wynika z przepisów prawa. Można by zatem dojść do wniosku, że in casu odrzucenie spadku godzi w osobisty charakter prawa do zachowku, ponieważ w sposób nieuprawniony służy wpływaniu na krag osób uprawnionych $\mathrm{z}$ tego tytułu. $\mathrm{Z}$ takim zapatrywaniem trudno się jednak zgodzić. Odrzucenie spadku jako dokonane antycypująco nie jest skuteczne aż do chwili ziszczenia warunku prawnego. Nie ma zatem potrzeby poszukiwania argumentów, które pozbawiałyby skuteczności tak dokonanej czynności prawnej. Poza tym sprzeczność czynności odrzucenia spadku z zasadą osobistości nie może mieć swojego źródła w motywacji, którą kieruje się dokonujący czynności prawnej. Sam fakt, że odrzucający spadek z tytułu ustawy zakładał, iż art. 1020 k.c. znajdzie $\mathrm{w}$ stosunku do niego zastosowanie (chociaż dziedziczenie nastapiło na podstawie testamentu) i możliwe będzie dochodzenie wyższego zachowku przez jego zstępnego, nie stanowi jeszcze wystarczającej podstawy do kwestionowania ważności dokonanej czynności.

${ }^{32}$ Por. Borysiak (2019): $1009 \mathrm{n}$.

${ }^{33}$ Por. Księżak (2012): 343.

${ }^{34}$ Księżak (2012): 343.

${ }^{35}$ Tak SN w uchwale z 23 października 2019 r., III CZP 23/19; co do osobistego charakteru prawa do zachowku zob. Księżak (2019): 941. 


\section{PODSUMOWANIE}

Po pierwsze, de lege lata nie ma podstaw do kwestionowania konstrukcji antycypujacego odrzucenia spadku. W prawie polskim - w ramach konstrukcji retroaktywnego nabycia spadku - obowiązuje bowiem conditio iuris, zgodnie z która skuteczność oświadczenia o odrzuceniu spadku jest zawieszona do momentu zaktualizowania się względem danej osoby ustawowych przesłanek dziedziczenia.

Po drugie, antycypujące odrzucenie spadku nie jest objęte treścią zakazu wynikajacego z art. $1018 \S 1$ k.c.

Po trzecie, wymogi natury praktycznej determinowane aktualnym kierunkiem orzecznictwa ${ }^{36}$ uzasadniają uzupełnienie przepisów prawa spadkowego o regulację, która w sposób wyraźny wskazywałaby na możliwość składania oświadczenia o przyjęciu lub odrzuceniu spadku począwszy od śmierci spadkodawcy.

Po czwarte, wzorem dla postulowanej regulacji mógłby być wspomniany już § 1946 BGB. Wprawdzie przepis ten nie zawiera wyraźnego odniesienia do konstrukcji antycypującego odrzucenia spadku, niemniej jednak w doktrynie niemieckiej powszechnie przyjmuje się, że § 1946 BGB stanowi źródło przedmiotowego uprawnienia. Nie ma natomiast potrzeby wprowadzania przepisów normujacych expressis verbis kwestię dopuszczalności antycypującego odrzucenia spadku.

Berek, M. (2019). Przedterminowe odrzucenie spadku. W nawiązaniu do uchwały SN z 19.10.2018 r., III CZP 36/18. Rejent 7(339): 31-53.

Borysiak, W. (2013). Dziedziczenie. Konstrukcja prawna i ochrona. Warszawa.

Borysiak, W. (2019). Komentarz do art. 1015 k.c., [w:] K. Osajda (red.), Kodeks cywilny. Komentarz. Tom 4A: Spadki. Warszawa: 996-1014.

Gorczyński, G. (2012). Oświadczenie o przyjęciu lub odrzuceniu spadku - uwagi de lege ferenda, [w:] A. Dańko-Roesler, J. Jacyszyn, M. Pazdan, W. Popiołek (red.), Rozprawy z prawa prywatnego. Księga pamiątkowa dedykowana Profesorowi Aleksandrowi Oleszce. Warszawa: 131-142.

Gorczyński, G. (2018). Komentarz do art. 1018 k.c., [w:] M. Habdas, M. Fras (red.), Kodeks cywilny. Komentarz. Tom 6: Spadki (art. 922-1087). Warszawa: 560-578.

Grykiel, J., Olejniczak, A., Radwański, Z. (2019). Rodzaje czynności prawnych, [w:] Z. Radwański, A. Olejniczak (red.), System prawa prywatnego. Prawo cywilne - część ogólna. Tom 2. Warszawa: 246-302.

Gutowski, M., Radwański, Z. (2019). Sankcje wadliwej czynności prawnej, [w:] Z. Radwański, A. Olejniczak (red.), System prawa prywatnego. Prawo cywilne - część ogólna. Tom 2. Warszawa: 542-586.

Gwiazdomorski, J. (1985). Prawo spadkowe w zarysie. Warszawa.

Jasiakiewicz, T. (2019). W poszukiwaniu środków ochrony prawnej małoletniego spadkobiercy przed mimowolnym przyjęciem spadku. Ruch Prawniczy, Ekonomiczny i Socjologiczny 81(4): $125-137$.

Justyński, T. (2019). Początek terminu do przyjęcia lub odrzucenia spadku. Glosa do uchwały Sądu Najwyższego z dnia 19 października 2018 r., III CZP 36/18. Orzecznictwo Sądów Polskich 11: 50-60.

${ }^{36}$ Uchwała SN z 23 października 2019 r., III CZP 23/19. 
Justyński, T. (2020). Glosa do uchwały SN z dnia 23 października 2019 r., III CZP 23/19. Orzecznictwo Sądów Polskich 7/8: 31-40.

Księżak, P. (2012). Zachowek w polskim prawie spadkowym. Warszawa.

Księżak, P. (2014). Glosa do postanowienia Sądu Najwyższego z dnia 20 listopada 2013 r., I CSK 329/13. Rejent 5(277): 105-111.

Księżak, P. (2015). Dobrodziejstwo inwentarza po nowelizacji Kodeksu Cywilnego z 2015 r. aspekty materialnoprawne. Kwartalnik Prawa Prywatnego 4: 875-910.

Księżak, P. (2017). Prawo spadkowe. Warszawa.

Księżak, P. (2019). Komentarz do art. 1002 k.c., [w:] K. Osajda (red.), Kodeks cywilny. Komentarz. Tom 4A: Spadki. Warszawa: 941-943.

Kucia, B. (2017). Oświadczenie o przyjęciu lub odrzuceniu spadku w imieniu małoletniego, [w:] M. Fras, P. Ślęzak (red.), Prawo prywatne wobec wyzwań współczesności. Księga pamiątkowa dedykowana Profesorowi Leszkowi Ogiegle. Warszawa: 219-227.

Kuźmicka-Sulikowska, J. (2019). Komentarz do art. 1015 k.c., [w:] E. Gniewek, P. Machnikowski (red.), Kodeks cywilny. Komentarz. Warszawa: 2061-2071.

Leipold, D. (2013a). Komentarz do art. 1946 BGB, [w:] S. Kessal-Wulf (Hrsg.), Münchener Kommentar zum Bürgerlichen Gesetzbuch. Band 9: Erbrecht. München: 235-236.

Leipold, D. (2013b). Komentarz do art. 1947 BGB, [w:] S. Kessal-Wulf (Hrsg.), Münchener Kommentar zum Bürgerlichen Gesetzbuch. Band 9. Erbrecht. München: 236-237.

Masloff, M. (2011a). Komentarz do § 1946 BGB, [w:] J. Damrau (Hrsg.), Praxiskommentar Erbrecht. Bonn: 154-155.

Masloff, M. (2011b). Komentarz do § 1947 BGB, [w:] J. Damrau (Hrsg.), Praxiskommentar Erbrecht. Bonn: 155-158.

Mularski, K., Radwański, Z. (2019). Zagadnienia ogólne czynności prawnych, [w:] Z. Radwański, A. Olejniczak (red.), System prawa prywatnego. Tom 2: Prawo cywilne - część ogólna. Warszawa: $1-60$.

Pazdan, M. (2021). Komentarz do art. 1012 k.c., [w:] K. Pietrzykowski (red.), Kodeks cywilny. Tom 2: Komentarz do art. 450-1088. Przepisy wprowadzające. Warszawa: 1284-1287.

Pisuliński, J. (1992). Niektóre problemy związane z terminem do złożenia oświadczenia o przyjęciu lub odrzuceniu spadku. Rejent 6(14): 54-75.

Siegmann, M., Höger, J. (2012a). Komentarz do § 1946 BGB, [w:] H. G. Bamberger, H. Roth (Hrsg.), Kommentar zum Bürgerlichen Gesetzbuch. Band 3. München: 1437.

Siegmann, M., Höger J. (2012b). Komentarz do § 1947 BGB, [w:] H. G. Bamberger, H. Roth (Hrsg.), Kommentar zum Bürgerlichen Gesetzbuch. Band 3. München: 1438-1439.

Swaczyna, B. (2012). Warunkowe czynności prawne. Warszawa.

Swaczyna, B. (2013). Odrzucenie spadku nabytego przez dziecko, [w:] E. Pecyna, J. Pisuliński, M. Podrecka (red.), Rozprawy cywilistyczne. Księga pamiątkowa dedykowana Profesorowi Edwardowi Drozdowi. Warszawa: 569-583.

Szpyt, K. (2019). Komentarz do art. 1015 k.c., [w:] M. Załucki (red.), Kodeks cywilny. Komentarz. Warszawa: 2094-2098.

Szymańska, A.M. (2010). Termin do złożenia oświadczenia o przyjęciu bądź odrzuceniu spadku. Białostockie Studia Prawnicze 7: 267-280.

Trimborn von Landenberg, D. (2011a). Komentarz do § 1946 BGB, [w:] W. Burandt, D. Rojahn (Hrsg.), Erbrecht. München: 88.

Trimborn von Landenberg, D. (2011b). Komentarz do § 1947 BGB, [w:] W. Burandt, D. Rojahn (Hrsg.), Erbrecht. München: 88-90.

Wolak, G. (2019). Glosa do uchwały SN z dnia 19 października 2018 r., III CZP 36/18. Rejent 7(339): 126-141.

Zelek, M. (2019). Przegląd orzecznictwa Izby Cywilnej Sądu Najwyższego (Październik 2018 r.marzec 2019 r.). Palestra 4(738): 107-114.

Żok, K. (2019). Komentarz do art. 1012 k.c., [w:] M. Gutowski (red.), Kodeks cywilny. Tom 3: Komentarz. Art. 627-1088. Warszawa: 1492-1499. 


\section{ON THE ADMISSIBILITY OF ANTICIPATORY REJECTION OF INHERITANCE IN POLISH LAW}

\section{Sum mary}

The prevailing view in the Polish doctrine and judicature is that after the death of the testator, the persons inheriting thereafter in the second and further sequence, have the right to reject the inheritance, as long as none of the persons appointed to inherit on a stronger basis wants to or can become an heir. This view is unfavourable for the persons appointed to the inheritance on a weaker basis. Earlier (anticipatory) rejection of the inheritance is assumed to be invalid, as performed under the condition that the person rejecting the inheritance would become the heir (Article $1018 \S 1$ of the Civil Code). This paper is the attempt to present criticism of such a view. In the opinion of the author, with the moment of the testator's death, the declaration on rejecting of the inheritance may be also made by the person appointed to the inheritance on a weaker basis, and thus inheriting in the second or further sequence. The effectiveness of such an act in law, due to the conditio iuris in force, is, however suspended until it turns out that the persons appointed to the inheritance on a stronger basis do not want to inherit or cannot become heirs. Thus, anticipatory rejection of the inheritance is admissible de lege lata. Given the discrepancies in the doctrine and unambiguous position of the judicature, the introduction of appropriate provisions into the Civil Code, similar to the regulation of $\S 1946$ BGB, is suggested in the article within the de lege ferenda comments.

Keywords: anticipatory rejection of the inheritance; rejection of the inheritance made under a condition; liability for inheritance debts; legitim 